\title{
Trade Law Needs to Be Better Incorporated into the UN Sustainable Development Goals
}

\author{
${ }^{1}$ School of Law, University of Reading, Berkshire, Reading RG6 6AH, United Kingdom \\ ${ }^{2}$ University of California San Diego, La Jolla, 92092, United States \\ ${ }^{3}$ Harbin No.3 High School, Harbin, Heilongjiang 150001, China \\ ${ }^{4}$ Nanjing Foreign Language School, Nanjing, JIANGSU 210008, China \\ ${ }^{5}$ High School Affiliated to Renmin University of China, Haidian, Beijing 100086, China \\ *Email: thgu58@outlook.com
}

*Shuyue $\mathrm{Gu}^{1}$, Cheng-Rui $\mathrm{Chi}^{2}$, Zihang $\mathrm{Gao}^{3}$, Wenxuan Tang ${ }^{4}$, Yumeng Duan

\begin{abstract}
With the development of economic globalization, the current world trade is developing quite rapidly. At the same time, however, various problems that need to be resolved have emerged. The climate problems caused by trade pollution to the environment are global, and the energy depletion and pollution problems caused by over-exploitation are even commonplace. In addition, the rapid development of trade seems to ignore the corresponding inequality issues, including but not limited to inequality between developed and developing countries, regional inequality, and income and wage inequality. Based on the problems that have emerged, the United Nations agreed in 2015 on a new set of Sustainable Development Goals (SDGs) as a universal call for action to eradicate poverty, protect the planet, and ensure peace and prosperity for all by 2030. The 17 Sustainable Development Goals are comprehensive-they recognize that actions in one area will affect outcomes in other areas, and development must balance social, economic, and environmental sustainability. This paper will discuss the external environmental impact of trade law and the inequality in development, analyze the current international trade and the solutions to the problems caused by it, and it also proposes innovative methods and recommendations for trade law to adapt to the sustainable development goals, especially in SDG13 and SDG10.
\end{abstract}

Keywords: UN Sustainable Development Goals, SDG 13, SDG 10, Trade Law

\section{INTRODUCTION}

The practice of international trade took place as early as the 16th century. Its history began with the traditional barter economy being replaced by mercantilism, featured by governments adopting high tariffs to pursue trade surplus. As the triangular trade routes were established, which enabled Europeans to acquire raw materials obtained from colonies, they were able to accumulate national wealth and increase consumptions. Although the 18 th century witnessed the flourish of economic liberalism led by economists such as Adam Smith in England, most of the western countries remained conservative and contended that trade can be desirable only when governments shelter domestic industries from trade and expand exports. Although protectionism was further intensified in the first half of the 20th century due to the collapse of the golden standard and the Great Depression, the establishment of the General Agreement on Tariffs and Trade (GATT) as well as the Bretton Woods System following the end of the World War II encouraged globalization and international trade. A significant force behind today's global economic development, international trade has become one of the main pillars supporting the global economy.

The 2030 Agenda for Sustainable Development, adopted by the United Nations (UN) in 2015, calls on all member states to make commitments to tackle global challenges and promote peace and prosperity for humanity and the planet. At the center of this initiative is the 17 Sustainable Development Goals (SDGs), two of which will be analyzed in combination with international trade in this paper. SDG 13 urges the government to take climate actions, while SDG 10 focuses on reducing inequalities within and among nations. 
Recent decades marked the growing conflicts between international trade and the progress of states achieving SDGs. For example, Foreign Direct Investment, which accounts for a large share of global trade volume, usually introduces production activities linked with carbon emissions to a nation, consequently impeding the process of carbon neutrality. Meanwhile, increased market competition, invented by trade liberalization, rendered the workers in import-competing sectors lose their job or receive fewer wages in some regions. Thus, rebalancing the pendulum between international trade and the pursuits of SDGs has become a critical concern for many professionals.

\section{WHY ARE THE SDGS IMPORTANT?}

The Anthropocene is termed "planetary boundaries" [1], stating that human activities are pushing global ecosystem functioning to a dangerous threshold, beyond which the planet is likely to suffer very potentially devastating outcomes. Threats from the environment and nature include: climate change, massive reduction in biodiversity, ocean acidification, environmental pollution, and more ${ }^{[1]}$. Meanwhile, human beings themselves create conflicts, and more concretely, inequalities. The income gap between workers with and without higher education has widened dramatically, both in developed and developing countries ${ }^{[1]}$.

Therefore, as an international organization with the participation of nearly 200 countries worldwide, the United Nation has approved the series of goals Sustainable Development Goals (SDGs) intended to achieve by 2030 through the United Nations General Assembly in 2015. "The 2030 Agenda for Sustainable Development, adopted by all United Nations Member States in 2015, provides a shared blueprint for peace and prosperity for people and the planet, now and into the future [2]." The SDGs list 17 heart issues designed to tackle common social issues globally. Its content includes improving health and education, environmental conservation, global economic growth, reduced inequality and others ${ }^{[2]}$. These are the goals that need to be addressed head-on in order for present and future human civilizations and the planet to reach common development, prosperity and flourishing.

In order to effectively implement the role of the Sustainable Development Goals, the UN Sustainable Development Group (UNSDG) ${ }^{[3]}$ serves for the role of decision making and policy development at the global level. At the regional level, the Regional Collaborative Platforms (RCP) ${ }^{[3]}$ brings together all UN entities to work on the issues raised in the SGDs in each region. At the same time, countries have committed to prioritizing the development of those who are lagging behind and helping to improve their livelihoods ${ }^{[4]}$. Furthermore, after the eight Millennium Development Goals (MDGs) adopted in 2000, the SDGs continue to build on the
MDGs by refining and developing the integration of topics such as equality, education, and environmental protection [5] with present-day issues. The SDG's objectives are relatively well set, its concrete implementation can reach into different areas and it covers almost all key issues.

"The Sustainable Development Goals are a call for action by all countries - poor, rich and middle-income to promote prosperity while protecting the planet... ${ }^{[6] "}$ As it stands, SGDs are a target-setting implementation that can be developed in depth. It is practical in all areas, from the state to the citizen, and can bring all the influences together ${ }^{[7]}$. Moreover, humanity could pave the way legally for more effective implementation of inclusive and sustainable development. It may also contribute to sustainable development if the global community is willing to establish legally binding rules [8]. The legal function may enhance the realization of SDGs, so they can be further promoted by improving international law.

\section{THE CONFLICTS BETWEEN SDG 13 AND INTERNATIONAL TRADE LAW}

The GATT, especially its Article XX when SDGs are being discussed, containing assorted exceptions to the obligations of trade liberalization, provides "opensource containers" for the potential of connecting different agreements and domestic law related to international trade.

One widely recognized case is US-Shrimps. The United States were sued under GATT Arts. XI, the action questioned being US banning the import of shrimp and related products from non-certified providers. The WTOAB decided that the chapeau of GATT Arts. XX was formed out of good faith, and should be interpreted by 'seeking additional interpretative guidance, as appropriate, from the general principles of international law'. ${ }^{[9]}$

Another well-known case would be the Mexico etc. Versus US: 'Tuna-Dolphin' Case. Like the US-Shrimps Case in which if a tuna exporter failed to meet US law, the US customs office would deport that country's fish. A panel was formed in February 1991. The panel reported to GATT members in September 1991. It favored Mexico in that the imports met Mexican regulations and that the unilateral US regulations should not be the reason to impose the embargo. The panel also concluded that GATT rules forbids one country to set trade barriers by forcing other countries to follow its domestic law.

In both cases WTOAB decided against the import restrictions of the US because enforcing trade protections based merely on the differences between the domestic laws implies the possibility of endless unrestricted limitations and de facto trade barriers. Any 
country could ban products from another country by stating that there is intractable conflict between different environmental, health and social policies if such restrictions were accepted. These protectionism abuses must be avoided for a better multilateral international trade system.

Domestic regulations are still respected and confirmed despite the restrictions were ruled improper. Quality and advertising standards were concluded not violating GATT rules. ${ }^{[9]}$

Obviously, SDGs could not have originated from these times when free trade prevailed. The Fall of the Berlin Wall and what was going on across the then Eastern Bloc confirmed the market economy's successes. With the Uruguay Round nearly reaching its conclusion and China's imminent enter into the world trade order, domestic restrictions on goods, however environmentally-friendly they were, had minimal effects on such a great trend of economic globalization.

Throughout international trade history, countries had been focusing on utilizing the market order for maximum gains and had not taken the development problems as a global issue. Even the very recent United Nations Millennium Development Goals (MDGs) were focusing on financial aids. The MDG were drafted by very few experts and UN officials. ${ }^{[10]}$ In this narrative, international trade law could hardly integrate issues like climate change and marine protection.

Years later, SDGs were drafted through comprehensive negotiating mechanisms aiming at solving global development with more holistic and inclusive approaches and global cooperation. The SDG preparatory phase has been largely an intergovernmental process held at the UN and under its rules. ${ }^{[11]}$ Missions to the UN of many countries joined the open consultations despite some of the issues at question being so professional. Though these favorable premises should have provided a whole new testing ground for harnessing international trade with legal instruments in that many rounds of negotiations have included diplomats from countries ranging from developing exporters relying on their stacks of raw materials to developed countries highly perched on the global value chains, the SDG drafting process failed to address trade matters pragmatically and directly where the EU directives had succeeded in European countries' legislations. Scholars attributed this result to various reasons including the unawareness of newest trade debate aspects and UN Missions' lack of intimate knowledge on so many goals related to international economics.

Now with the uncertainty of global future and emergence of international challenges, whatever is the case before, the international trade law system now faces a great opportunity to reform adapting to the needs of SDGs and their ultimate grail of "better life".

Among the Sustainable Development Goals, the SDG13 is gaining evermore attention from all sectors in recent years. SDG13, titled Climate Action, with the effort of most of the sovereign states and countless NGOs including Greenpeace and Rainforest Alliance to address climate change mitigation and adaptation, is often seen as the opposite force of trade liberalization for its implications of limitation on fossil fuels and emissions, etc. The free trade is reality. It had already helped countries make immense progress in economy, society and even many SDG fields. With the relatively unobstructed flow of goods, the world could better tackle with universal challenges together. But climate change, along with collateral negative impacts are the imminent threat to the whole humankind. SDG13 is noticeably brief on issues around reduction of greenhouse gas (GHG) for that the Paris Agreement was not finalized by then.

As discussed above, there in international trade law system already are generally accepted articles addressing the environment issue, but for several instances seemed failed to protect the environment as they should have. Years after the resolution of this USShrimps case, one curious part in the WTOAB's report is still shedding new light upon the incorporation of international law with SDG, in which it suggests that the Arts. XX to be read in the light of contemporary concerns of the community of nations about the protection and conservation of the environment'. ${ }^{[11]}$ The WTOAB reached the conclusion that the ban was arbitrary and unfair and thus illegal. The ban was ruled unjustifiable because of its intention and de facto coercion on WTO member states' policy-making and legislation. The unilateral nature of the imposition also added to its arbitrariness. ${ }^{[9]}$ Arbitrary and nontransparent bans are in direct conflict with the ideals of free trade.

A successful Art. XX defense means blazing a trail through the first two, Subject Matter/Scope and Qualifiers, and the third checkpoint of Art. XX chapeau. The above three combined, often pose great challenges for the Respondent to justify the trade restriction under question.

The two cases discussed above were classified into the failing chapeau threshold group. As for the other two scenarios, there were instances where the scope question would terminate the proceedings such as in the EC Tariff Preferences case, WTOAB decided that the E.C. counter-narcotic tariff measures were more economical than social-welfare-oriented. ${ }^{[12]}$ In other cases like the China - Rare Earths (2014) Case, China's action of export restrictions on a particular set of raw materials could not be justified and was ruled inconsistent with WTO rules. 
SDG13's field, Climate Change, has been rarely mentioned in GATT Art. XX cases so far. Part of the reason could be that the climate change issue is hardly the direct motive behind most international trade restrictions. Crude oil industries in many countries are strictly under government administration which implies that the global oil market is at most a "free market only with the silent consensus of sovereign states". Rather, fossil fuels as the origin of greenhouse gases and probably climate change, are universal and irreplaceable in many ways that wherever the fuels are consumed the immediate products and final goods exports would still flow into the global trade market, making the emissions released in industrial production hard to estimate and limit. The GHG issue is now partially solved by Emissions Trading System where countries are given Nationally Determined Contributions (NDCs) and can trade emission quantity limits within the framework.

But the issue does not disappear with this new system. In countries that establish a cap-and-trade system where a company purchases the permits for emissions, relocation of big emitters to more forgivable countries remain a popular option.

The European Union legislation bodies have set targets and standards for clean energy and made the EU member states follow the rules, creating obvious discrimination of bio-fuel sources. ${ }^{[13]}$

In general, motives and foreseeable consequences often mismatch when SDG13 and international trade law are discussed together. The greatest issue still lies within the WTOAB's interpretation of the current WTO Agreements if no new written agreements were officially accepted into the WTO system.

\section{INTERACTION BETWEEN THE CURRENT INTERNATIONAL TRADE LAW AND CLIMATE CHANGE}

The connection between international trade law and SDG 13 strengthened after the Paris Conference as the international legal system began to consider how certain trade policies may impede actions toward climate change ${ }^{[13]}$. This close connection is apparent in both the trade in services and goods. Trade in services play a major role in reducing climate change because an increased productivity in service will reduce the usage of energy and the intensity of emissions. As one of SDG 13 's target is to integrate the prevention of climate change in policies, the current international trade law should set policies to increase the productivity in the service sector of trade to prevent the worsening of climate change ${ }^{[14]}$. As the efficiency of trade in services increase, the productivity of the manufacturing sector will also increase. This suggests that more eco-friendly goods can be efficiently manufactured ${ }^{[15]}$. As one of SDG 13's other targets is to increase the knowledge people know about climate change, the international trade law should include policies that will allow more manufacturing firms to understand the dangers of releasing large amounts of carbon as well as the danger of manufacturing goods that will pollute the environment. This will allow SDG 13 to be better integrated into the international trade law, thus reducing potential worsening in climate change.

The most important change that should be implemented in the current international trade law to address SDG 13 is to increase global trade in environmentally friendly goods. This will help to alleviate environmental problems and improve the global economy. The international trade law should continue to encourage OECD (Organization for Economic Co-operation and Development) countries to reduce import tariffs for goods that are environmentally friendly. As formal trade barriers still exist for certain environmental goods, the international trade law should be reformed so that these barriers can be reduced ${ }^{[15]}$.

\section{THE INEQUALITIES BETWEEN SDG10 AND TRADE LAW}

Sustainable Development Goal 10 (SDG 10) targets on reducing inequality within and among countries. As structured, it implies that the real concern is with equity, namely with the equality of an economic system in terms of determining how wealth is distributed and whether all have an equal life chance within it ${ }^{[16]}$. Rising inequality will lead to social unrest and political instability, which will undermine economic growth. The increasing inequality caused by international trade has become an extremely serious concern for many people in the world, including policymakers and researchers ${ }^{[17]}$. Reducing inequalities and achieving more balanced growth have been incorporated into governments' political agendas.

First and foremost, we examined the impact of international trade from a global perspective. The inequalities between developing and developed countries were analyzed according to the PrebischSinger hypothesis ${ }^{[18]}$. Developing nations tend to become the leading exporters of raw materials and energy in the international market and import industrial goods, which allows developed nations to deprive valuable natural resources from developing nations. As time goes by, the natural resources of developing countries are overexploited while their environmental conditions worsen dramatically. The emissions of hazardous gases, along with the deterioration of natural environment, not only renders production activities deficient but also adversely impact people's lives. ${ }^{[19]}$ Goff and Singh analyzed panel data covering 30 African countries from 1981 to 2010 in 2013 and found that the impact of trade on poverty is negative, which means that trade has exacerbated a nation's poverty unless its 
financial sector is highly developed and it can provide high-quality top education. ${ }^{[20]}$

Secondly, increased inequalities within nations resulted from trade liberalization were also examined. Pal and Ghosh contend that financial reforms, foreign and domestic investment liberalization, and trade liberalization all exacerbate domestic inequalities as they promote the flows of financial resources from the poor to the rich. They also believe that international trade imposes negative effects on agriculture sectors that employs low-income workers and benefits only a small part of the manufacturing industry, leading to widened inequalities. Their arguments are in line with the conclusions of Hecksher-ohlin trade model. The model suggests that the nation that is abundant in a factor exports the good whose production is intensive in that factor. For example, a developed nation would export capital-intensive products because it is endowed with sufficient capitals. Under such circumstances, trade would hurt its scare production factors deployed in import sectors, such as unskilled labors, by driving down the relative price of the products they produced. Eventually the income gap would be widened. ${ }^{[21]}$ This argument is support by Ragayah's research on income inequality which found that with the emergence of labor shortages in the 1990s, developing countries like Malaysia upgraded their labor-intensive industrialization to capital and technology-intensive industrialization to maintain global competitiveness. ${ }^{[2]}$ This new development strategy has changed the labor demand pattern of the industry, making it tilt towards skilled and educated workers and leading to increased income inequalities.

\section{HOW TO REFORM WTO TO REDUCE INEQUALITIES}

Given the above arguments, it is evident that the current international trade did exacerbate economic inequalities within and among countries to some extent. Reforming the GATT agreement to tackle or eradicate these issues has become the primary concern for many policy-makers and economists. After deliberate consideration and careful analysis, our team collectively came up with a proposal for WTO reform with the aim to resolve the fierce conflict between trade and equality while promoting global economic development, which will be shown in the following paragraphs.

First of all, the WTO is recommended to concede itself to sovereignty nations instead of forcing its member states to amend domestic legislation and regulations to invent conditions advantageous for the development of free trade. Despite the fact that trade makes everyone better off, as it was illustrated by Adam Smith in his book Wealth of Nations [23], GATT agreement ought to guarantee nations more room to determine the extent of openness in accordance with their different economic systems for their national developments rather than compelling them to be deeply incorporated into the global trading system. Under such circumstances, countries could carry out trade policies compatible with their economic guiding principles, adopt a more flexible posture in international trade rather than being constrained, and increase their aggregate incomes measured by Gross Domestic Product (GDP). The reason that economic development happened in China, Japan, and South Korea in recent decades lies in that all of their governments could fully control the allocation and cross-border flow of their capitals, adjust the value of their currencies, and undertake formal and informal trade barriers to shelter some crucial industries from foreign competition ${ }^{[24]}$. Blindly pursuing the economic gains of free trade while overlooking its defects would hinder a nation's development.

In addition, the WTO is advised to enact series of policies and bills protecting labor welfare in collaboration with governments across the world, including but not limited to the minimum wage act, unemployment insurance network, and income support programs, with the intention of providing local workers affected by the international trade with financial assistance, helping them receive the attention due. Take the Trade Adjustment Assistance (TAA) program carried out by the federal government of the United States of America as an example. It aims to provide financial support to workers that have lost their unemployment or whose wages are reduced due to increased imports through a variety of programs and reemployment services. ${ }^{[25]}$ Although its effectiveness is still being debated by experts up to this day, it serves as a model that politicians can use for reference.

\section{RECOMMENDATION}

For trade law to be better incorporated into the UN Sustainable Development Goals, two pieces of recommendation would be given to this issue. The first piece of recommendation is that countries should actively follow the SDGs without abusing the international trade law system to reach unfair trade advantages. Examples of unfair trade advantages may be setting trade barriers on goods that are eco-friendly to the environment for a country's own benefit. The second piece of recommendation is that the recent WTO negotiation rounds and trade agreements between countries include updates to the exceptions clause and breach clause to integrate the newest consensus reached in the global community like the Paris Agreement.

\section{CONCLUSION}

We analyzed the current conflicts between trade law and the Sustainable Development Goals, especially in 
the aspects of SDG10 and SDG13. In terms of theory, trade law needs to be reformed to adapt to the goals of sustainable development. From the perspective of climate action, the excessive development and utilization of natural resources by trade have brought climate problems and environmental pollution, which will not be conducive to sustainable economic development. From the perspective of inequality, trade has brought about inequality between developed and developing countries, income and wage inequality, and regional inequality, which has a negative impact on the economy and trade of the global market.

After discussing the conflict between trade and the Sustainable Development Goals, we put forward thoughtful suggestions on both climate action and inequality. From the perspective of SDG13, in order to solve the global climate and environmental problems, we should increase the global production and circulation of environmentally friendly products. The state should reduce tariffs on environmentally-friendly products, and facilitate the exit and entry of environmentally-friendly products. If the international trade law can be effective to prohibit trade barriers to the import and export of environmentally friendly products and encourage the trading of environmentally friendly products, the situation will be better. From the perspective of SDG10, in order to solve the problem of inequality, the WTO should play its role in creating a fair-trading environment for international trade and adopt more flexible policies to balance the inequality of trade between countries. The relevant state agencies should formulate effective and feasible economic policies to promote the increase of GDP. On the basis of maintaining the SDT regulations, the WTO should clearly define the criteria used to distinguish developed and developing countries, promote the economic growth of poor people, and further promote the fairness of international market competition. In addition, the WTO is obliged to work with governments around the world to formulate a series of policies and bills to protect labor welfare.

Trade law still needs further reform to better incorporate with the sustainable development goals.

In terms of reforming the trade law, we have made analyses and suggestions from the perspective of SDG10 and SDG13, but we still have a long way to go to actually improve the environment and inequality. Due to the limitation of knowledgeability and level at this stage, the recommendations we put forward are only based on theory and not actually carried out. We suggest that future scholars, when conducting research in this field, can explore the extent to which trade law and international organizations can be reformed to better adapt to the goals of sustainable development.

\section{REFERENCES}

[1] Sachs, Jeffrey D. (2012) From Millennium Development Goals to Sustainable Development Goals. The Lancet, vol.379, pp. 2206-2211.

[2] United Nations. (2015) The 17 Goals sdgs.un.org/goals.

[3] United Nations Sustainable Development Group. (2021) UNSDG | UN in Action - Global Level. unsdg.un.org/un-in-action/global-level.

[4] United Nations Development Programme. (2015) Sustainable Development Goals | UNDP. www.undp.org/sustainable-development-goals.

[5] United Nations. (2000) 55/2 United Nations Millennium Declaration. In: The Millennium Assembly of the United Nations, New York. pp. 47.

[6] Neshovski, Robert. (2018) United Nations Sustainable Development. www.un.org/sustainabledevelopment/.

[7] Griggs, D., Stafford-Smith, M., Gaffney, O. et al. (2013) Sustainable development goals for people and planet. Nature 495: 305-307.

[8] Gupta, J., Vegelin, C. (2016) Sustainable development goals and inclusive development. Int Environ Agreements 16: 433-448.

[9] United States Import Prohibition of Certain Shrimp and Shrimp Products. (1998) WTO Dispute Settlement Body. WT/DS58/AB/R.

[10] Messerlin, P. (2017) From MDGs to SDGs: The Role of Trade. Asian Development Bank Institute.

[11] Lunn, J., E. Downing, and L. Booth (2015). The SDGs and the Post-2015 Development Agenda. Briefing paper.

[12] Panel Report, EC - Tariff Preferences, at para.

[13] Mitchell, A., \& Tran, C. (2010). The Consistency of the European Union Renewable Energy Directive with World Trade Organization Agreements: The Case of Biofuels. Renewable Energy Law and Policy Review, 1(1), 33-44.

[14] The Global Goals. "Goal 13: Climate Action." The Global Goals. https://www.globalgoals.org/13climate-action.

[15] Matthias, H., \& Shepherd, B. (2018). WIN-WinHow International Trade Can Help Meet the Sustainable Development Goals. Asian Development Bank.

[16] Carpentier, C., Kozul-Wright, R., \& Passos, F. (2015). Reduce inequality within and among 
countries. UN Chronicle, 51(4), 23-25.[18] Harvey, David I., et al. "the Prebisch-Singer Hypothesis: Four Centuries of Evidence." The Review of Economics and Statistics, vol. 92, no. 2, 2010, pp. 367-377.

[17] Helpman, E., Itskhoki, O., Muendler, M., \& Redding, S. (2016). Trade and Inequality: From Theory to Estimation. The Review Of Economic Studies, 84(1), 357-405.

[18] Harvey, D., Kellard, N., Madsen, J., \& Wohar, M. (2012). Erratum to 'The Prebisch-Singer Hypothesis: Four Centuries of Evidence'. SSRN Electronic Journal.

[19] Krugman, P. R., Obstfeld, M., \& Melitz, M. (2017). International trade: Theory and policy, global edition (11th ed.). Pearson Education.

[20] Le Goff, M., \& Singh, R. (2014). Does trade reduce poverty? A view from Africa. Journal Of African Trade, 1(1-2), 5.

[21] Inequality in India: A Survey of Recent Trends. Un.org. (2021). Retrieved 7 November 2021, from http://www.un.org/esa/desa/papers/2007/wp45_200 7.pdf.

[22] RAGAYAH, H. (2008). Income Inequality in Malaysia. Asian Economic Policy Review, 3(1), 114-132. https://doi.org/10.1111/j.17483131.2008.00096.x

[23] Smith, A. (2008). An inquiry into the nature and causes of the wealth of nations: A selected edition. London, England: Oxford University Press.

[24] Rodrik, D. (2012). The globalization paradox: Why global markets, states, and democracy can't coexist. Oxford University Press.

[25] U.S. Department of Labor. (2021) "Trade Act Programs | U.S. Department of Labor.”. www.dol.gov/general/topic/training/tradeact. 